\title{
Maturation Diets for Ornamental Fishes - An Analysis
}

\author{
Gowsalya T* and Stephen Sampath Kumar J \\ Thanjavur Centre for Sustainable Aquaculture, India
}

Submission: November 11, 2017; Published: February 13, 2018

*Corresponding author: Gowsalya T, Thanjavur Centre for Sustainable Aquaculture, Thanjavur-614 904, India, Email: gowsalya91.thangasamy@gmail.com

\begin{abstract}
Ornamental fishes offer great entrepreneurial scope in tropical countries. Breeding of ornamental fishes is essential for trading the youngones which would get higher price. The maturation of ornamental fishes is a subject that needs great attention now. Diets support maturation and breeding ability of ornamental fishes. Research on maturation diet for ornamental fishes is another area in fish nutrition. Identification of additives that will make maturation diets really working in captivity is felt essential. The additives of both plant and animal origin have equal important in maturation diet as evidenced from fish nutrition studies. The present article deals with an analysis of some of the important feed additives that can be used in ornamental maturation diets. Opinions and reports that are available on closely related have been referred and analyzed.
\end{abstract}

Keywords: Plant origin; Animal origin; Ornamental fishes; Maturation diets; Gonad development

\section{Introduction}

Nutrient requirement of ornamental fishes vary from species to species. Optimum nutritional support is essential for the fish to get maturation in confined waters. The maturation and spawning of the fish can be improved through the nutritional quality of broodstock diet as respected by many researchers. There is need to control the cost of feed that is used in the ornamental fish farming, which can help in large scale adoption of the formulated diet for broodstock management.

Goldfishes are hardy in nature as they can survive in poor water quality also. It is an omnivore, which feeds on wide variety of live and artificial feeds. The natural diet consisted of animal matter like fragments of crustaceans, insects and their larvae, detritus and various plant matters which meet their protein requirement. Ortega and Reyes reported that naturally goldfishes reproduce in the wild and reach sexual maturity between first and second year. Further feeding with live feeds enhance their breeding habits. Youngones of gold fishes mainly feed on green algae followed by infusoria, daphnia, moina and tubifex. Adult goldfishes of 8 to 15 months of age ranging in size from 40 to $100 \mathrm{~g}$ can be used as broodstock and they can be fed with live feeds such as tubifex, earthworm, bloodworm etc.

Broodstock nutrition plays a major role in the development of gonads. The dietary requirement of broodstock is different from those of rapidly growing juvenile fishes. The role of nutrients and supplementary feeds on regulating the reproductive physiology of broodstock is well documented. Nutrient requirements vary depending on species, size, developmental status, sex, gonad and egg maturation process. There are many reports on the influence of nutrition on growth, gonad maturation and reproduction in ornamental fishes. It has been reported that reduction in feeding rate can cause an inhibition of gonadal maturation in several fish species including goldfish. Since, the diets play a major role in the maturation and further breeding of ornamental fishes. Maturation diets have been analyzed with due focus of suitable feed additives.

\section{Maturation Diets}

Feed contributes $60-80 \%$ of the total operational cost in aquaculture system which is a major challenge for aquaculture industry. Feeding of ornamental fishes is difficult when compared to pond fish culture due to limitation of space and lack of natural food. Despite the popularity ornamental fishes have worldwide, micro level nutritional requirement for breeding has not been studied well. Feeding practices for ornamental fish differ from food fish. Stone et al. estimated that the feed cost for ornamental fishes like gold shiner, goldfish and flat head minnows is about $18 \%$ of total cost. Therefore, a low cost feed is necessary for successful business in ornamental fish production.

In commercial formulated feeds, fish meal is the major source of protein. Excessive use of feed with such protein rich ingredients leads to water pollution. It is essential to avoid water 
pollution and minimize the ammonia excretion. The availability of fish meal is also in critical situation due to stagnation in capture fisheries and increased price. Therefore, there is a need to select an alternative protein source for preparing commercial feeds for ornamental fishes.

\section{Plant protein additives}

The natural feed additives in aqua feed production are broadly classified into three types based on their origin viz., plant protein additive, animal protein additive and microbial protein additive. It is reported that the increased use of plant protein sources such as cereals, pulses, soy bean meal, legumes in fish diet can reduce the cost of feed. Although high dietary levels of plant proteins are present in feed, it can affect the growth performance by reduced feed consumption due to anti nutritional factors and cellulose present in its cell wall which cannot be digested by aquatic animals. Since, the above popular feed additive have their own limitation, there is a need to search new alternative plant protein sources which can reduce feed cost and improve the feed efficiency.

Spirulina is a plant protein source that has been widely reported for use as an additive. Cell wall of Spirulina is made up of mucoprotein which can be easily digested by fishes and used for enhancing the growth and reproduction.

\section{Animal protein additives}

Commonly used animal protein source in aquafeed is fish meal. The availability of fish meal is decreasing and therefore the price is increasing during the last decades. This has forced aquaculturists to identify and evaluate alternate animal nutrient sources for aquaculture. There are many alternatives found available and used experimentally in the place of fish meal under and few of them were adjudged suitable for aquafeeds.

\section{Spirulina as a special feed additive for the development of gonad in ornamental fishes}

James et al. observed four times greater gonad weight in Swordtail when fed with $8 \%$ Spirulina diet. This might be due to greater availability of protein and gonad stimulatory substances. When Spirulina concentration is further increased in feeds, it was found to decrease feeding efficiency consequently reducing growth and gonad development. In a study by James et al. fish fed with Spirulina mixed with $300 \mathrm{mg}$ Vitamin E diet had significantly higher growth performance, gonad weight and GSI infemale goldfish and produced five times higher gonad weight than control fishes.

Beresto reported that Spirulina has mucopolymer "murein" in its cell wall instead of cellulose which increased the palatability of the Spirulina diet that can be easily digested by the digestive enzymes secreted by fish.

\section{Earthworm as a special additive for development of gonad in ornamental fishes}

Keong suggested that earthworm meal can be used as a source to induce maturation in cultured shrimp due to presence of poly unsaturated fatty acids in the meal which will help to trigger maturation in shrimp under captivity. Ramu who mentioned the presence of prostaglandins related compounds in earthworms and these hormones could have possibly induced gonadal maturation in fish and shell fishes.

\section{Shrimp head meal as a special additive for development of gonadin ornamental fishes}

Placentia- Jatomea et al. found that Tilapia when fed with feed containing shrimp head silage at $15 \%$ level produced higher growth performance when compared to control fishes. They also reported that certain amount of shrimp head meal in the diet can improve the growth performance. This can be equated with that of gold fish.

Akiyama et al. reported that diet containing 15\% shrimp head meal had the ratio of lysine and arginine closer to recommended ratio for shrimp. The higher quantities of lysine and arginine in the muscular protein of shrimp waste can improve the growth of fishes. They also reported that the lesser level of inclusion of shrimp head meal than $15 \%$ in the diet reduced the protein availability for fishes consequently it reduced the growth of fishes. These findings are found true in the present study.

\section{Conclusion}

From the analysis, it can be concluded that Spirulina, earthworm meal and shrimp head meal when included in the feed at different level can improve the performance of ornamental fishes in terms gonad maturation. However, the cost benefit analysis is required to further recommend the right feed additive for the goldfish maturation diets. 
(c) (1)

This work is licensed under Creative Commons Attribution 4.0 Licens

DOI: 10.19080/OFOAJ.2018.06.555686
Your next submission with Juniper Publishers will reach you the below assets

- Quality Editorial service

- Swift Peer Review

- Reprints availability

- E-prints Service

- Manuscript Podcast for convenient understanding

- Global attainment for your research

- Manuscript accessibility in different formats

( Pdf, E-pub, Full Text, Audio)

- Unceasing customer service

Track the below URL for one-step submission https://juniperpublishers.com/online-submission.php 